\title{
HUBUNGAN PENGGUNAAN FASILITAS BELAJAR DAN MOTIVASI BELAJAR DENGAN HASIL BELAJAR EKONOMI
}

\author{
Oleh \\ Jojon Susanto*, Sonedi** \\ Email.sonedibaldi@gmail.com
}

\begin{abstract}
The purpose of this study was to determine whether there was a significant relationship between: (1) the use of learning facilities with results, (2) motivation to learn with learning outcomes, (3) use of learning facilities and motivation to learn with learning outcomes. This research is quantitative descriptive. the number of samples is 104 . The sample selection uses the Probability Sampling technique of simple Random Sampling. Data was collected using questionnaire and documentation methods. Test requirements analysis using the Normality test. The results of the study: (1) There is a positive relationship between the use of learning facilities and learning outcomes, analysis: rx1y $=0.206$ and rtable $=0.195$. (2) There is a positive relationship between motivation to learn and learning outcomes, analilis: $r x 2 y=0.225$ and rtable $=0.195$. (3) There is a shared positive relationship between the use of learning facilities and learning motivation with learning outcomes, analysis: $r x 1 x 2 y=0.298$ and rtable $=0.195$. The relationship is included in the low category because based on the calculation of the coefficient of determination the relationship between the use of learning facilities and learning motivation with economic learning outcomes is found at $8.88 \%$.
\end{abstract}

(C) Muhammadiyah University of Palangkaraya

Keywords: Use of Learning Facilities, Learning Motivation, and Economic Learning Outcomes

\begin{abstract}
ABSTRAK
Tujuan penelitian ini adalah untuk mengetahui ada tidaknya hubungan yang signifikan antara: (1) penggunaan fasilitas belajar dengan hasil, (2) motivasi belajar dengan hasil belajar, (3) penggunaan fasilitas belajar dan motivasi belajar dengan hasil belajar. Penelitian ini merupakan penelitian deskriptif kuantitatif. jumlah sampel sebanyak 104. Pemilihan sampel menggunakan teknik Probability Sampling jenis simple Random Sampling. Data dikumpulkan dengan menggunakan metode angket dan dokumentasi. Uji persyaratan analisis menggunakan uji Normalitas. Hasil penelitian: (1) Ada hubungan positif antara penggunaan fasilitas belajar dengan hasil belajar, analisis: rx1y $=0,206$ dan rtabel $=0,195$. (2) Ada hubungan positif antara motivasi belajar dengan hasil belajar, analilis: $\mathrm{rx} 2 \mathrm{y}=0,225$ dan rtabel $=0,195$. (3) Adanya hubungan positif bersama antara penggunaan fasilitas belajar dan motivasi belajar dengan hasil belajar, analisis: $\mathrm{rx} 1 \mathrm{x} 2 \mathrm{y}=0,298$ dan $\mathrm{r}_{\text {tabel }}=0,195$. Hubungan tersebut termasuk dalam kategori rendah karena berdasarkan perhitungan koefisien determinasi hubungan antara penggunaan fasilitas belajar dan motivasi belajar dengan hasil belajar ekonomi ditemukan sebesar $8,88 \%$.
\end{abstract}

(C) Universitas Muhammadiyah Palangkaraya

Kata Kunci: Penggunaan Fasilitas Belajar, Motivasi Belajar, dan Hasil Belajar Ekonomi. 


\section{PENDAHULUAN}

Pendidikan adalah usaha sadar untuk menumbuh kembangkan potensi SumberDaya Manusia (SDM). Upaya peningkatan mutu pendidikan menjadi bagianterpadu dari upaya peningkatan kualitas manusia, baik aspek sosial, kepribadian, maupun tanggung jawab sebagai warga masyarakat. Selain itupendidikan juga merupakan faktor penting dalam kemampuan seseorang untukmemecahkan masalah di dalam kehidupannya. Kemampuan dan keterampilanyang dimiliki seseorang tentu akan sesuai dengan tingkatan jenjangpendidikan yang diikutinya. Dapat dikatakan bahwa jika seseorang memilikitingkat pendidikan yang tinggi maka akan semakin baik pula kemampuan, keterampilan, dan ilmu pengetahuan yang dimilikinya. Pasal 1 ayat 1 Undang-Undang Nomor 20 Tahun 2003 tentang SistemPendidikan Nasional dijelaskan bahwa: Pendidikan adalah usaha sadar danterencana untuk mewujudkan suasana belajar dan proses pembelajaran agarpeserta didik secara aktif mengembangkan potensi dirinya untuk memiliki kekuatan spiritual keagamaan, pengendalian diri, kepribadian, kecerdasan, akhlak mulia, serta keterampilan yang diperlukan dirinya, masyarakat, bangsadan negara.

Dalam hal ini berarti dalam praktik usahanya pendidikanbertujuan untuk mewujudkan suasana belajar yang aktif sehingga dapatmeningkatkan segala potensi yang ada dalam diri peserta didik. Peningkatan perkembangan peserta didik dapat dilakukan dengan cara memberikan bimbingan, latihan atau pembiasaan yang diarahkan dalam rangka mengembangkankepribadian dan kemampuan peserta didik ke arah yang lebih baik. Melalui pendidikan diharapkan dapat mencetak generasi berkualitas yangakan berkontribusi dalam tercapainya tujuan pembangunan nasional. Dalam Pasal 3 UndangUndang Nomor 20 Tahun 2003 tentang Sistem PendidikanNasional disebutkan bahwa: Pendidikan nasional berfungsi mengembangkan kemampuan danmembentuk watak serta peradaban bangsa yang bermartabat dalam rangka mencerdaskan kehidupan bangsa, bertujuan untuk berkembangnya potensipeserta didik agar menjadi manusia yang beriman dan bertakwa kepadaTuhan Yang Maha Esa, berakhlak mulia, sehat, berilmu, cakap, kreatif, mandiri, dan menjadi warga negara yang demokratis serta bertanggungjawab.

Pewujudan tujuan pendidikan nasional perlu diimbangi dengan peningkatan mutu pendidikan. Mutu pendidikan sangatlah erat kaitannya dengan mutu guru dan mutu peserta didik. Guru sebagai pengelola kegiatan pembelajaran merupakan faktor penentu kunci keberhasilan dalam pelaksanaan pendidikan. Seorang guru yang profesional tidak cukup hanya dengan menguasai materi pelajaran saja, akan tetapiharus mampu mengayomi, menjadi contoh, dan selalu mendorong peserta didik untuk lebih baik dan maju. Selain faktor guru, dalam mewujudkan peningkatan mutu pendidikan juga tidak terlepas dari faktor peserta didik. Oleh karena itu, dalam peningkatan mutu pendidikan haruslah pula diikuti dengan 
peningkatan mutu peserta didik. Peningkatan mutu peserta didik dapat dilihat pada tingkat hasil belajar peserta didik. Bagi seorang peserta didik mendapatkan hasil belajar yang baik merupakan sebuah kebanggaan. Akan tetapi, untuk mendapatkan hasil belajar yang baik bukanlah hal yang mudah, karena keberhasilan belajar peserta didikdipengaruhi oleh beberapa faktor dan memerlukan usaha yang besar untuk meraihnya.

Menurut Slameto (2010: 2) pengertian belajar secara psikologis belajar merupakan suatu proses perubahan yaitu perubahan tingkah laku sebagai hasil dari interaksi dengan lingkungannya dalam memenuhi kebutuhan hidupnya.

Perubahan yang terjadi dalam diri seseorang banyak sekali baik sifat maupun jeisnya karena itu sudah tentu, tidak setiap perubahan dalam diri seseorang merupakan perubahan dalam arti belajar. Menurut James $\mathrm{O}$. Whittaker (dalam Djamarah, 2007: 12) merumuskan belajar sebagai proses dimana tingkah laku ditimbulkan atau diubah mealui latihan atau pengelaman.

Dari beberapa pengertian tersebut dapat disimpulkan bahwa pada pokoknya belajar adalah suatu kegiatan yang menimbulkan perubahan dalam diri seseorang dari tidak tahu menjadi tahu yang ditandai adanya pengetahuan, sikap dan keterampilan diperolah baik di sekolah maupun di rumah atau di masyarakat.

Menurut Dalyono (2012:55) menyatakan: Berhasil atau tidaknya seseorang dalam belajar disebabkan beberapa faktor yang mempengaruhi pencapaian prestasi belajar yaitu berasal dari dalam diri orang yang belajar (internal) meliputi kesehatan, intelegensi dan bakat, minat dan cara belajar serta ada pula dari luar dirinya (eksternal) meliputi lingkungan keluarga, sekolah, masyarakat, dan lingkungan sekitar.

Dengan menggunakan fasilitas belajar secara maksimal peserta didik akan lebih mudah dalam memahami pelajaran, karena dengan penggunaan fasilitas belajar maka proses belajar akan lebih mudah dan hal ini juga akan mempengaruhi daya serap peserta didik terhadap materi pelajaran. Penggunaan fasilitas belajar merupakan salah satu sarana yang memberikan pengaruh bagi peserta didik dalam melaksanakan proses belajar. Mengingat fasilitas belajar yang disediakan di SMA Muhammasiyah 1 Palangka Raya cukup tersedia, selain gedung sebagai fasilitas utama kegiatan belajar mengajar, ada fasilitas lainnya berupa laboratorium komputer, hotspot area, perpustakaan, serta fasilitas-fasilitas lainnya, dengan fasilitas belajar yang cukup tersedia tersebut, kenapa hasil belajar yang dicapai oleh peserta didik masih rendah, ketersediaan fasilitas belajar yang cukup tersedia jika tidak diimbangi dengan penggunaan yang optimal, maka hasil yang didapatkan akan sama saja dengan pembelajaran dengan fasilitas yang minim, sehingga dapat dikatakan penggunaan fasilitas belajar masih dapat dikatakan kurang. Jika penggunaan fasilitas belajar kurang optimal, proses belajar yang seharusnya semakin lancar dan mencapai hasil belajar yang tinggi menjadi terhambat, sehingga perlu 
diketahui bagaimanakah penggunaan fasilitas belajar yang ada di sekolah dalam meningkatkan pemahaman materi pelajaran, serta seberapa besarkah hubungannya jika dikaitkan dengan hasil belajar yang diperoleh siswa kelas X di SMA Muhammaduyah 1 Palangka Raya.

Penggunaan fasilitas belajar peserta didik harus dilengkapi dengan motivasi belajar peserta didik. Menurut Sardiman (2012:75) motivasi adalah: Keseluruhan dayapenggerak di dalam diri siswa yang menimbulkan kegiatan belajar yangmenjamin kelangsungan dari kegiatan belajar dan memberikan arah sehingga tujuan yang dikehendaki dapat tercapai.

Motivasi belajar mempunyai peranan penting dalam kegiatan belajar seseorang. Motivasi belajar menurut Uno (2012:23) adalah: Dorongan internal dan eksternal pada siswa-siswa yang sedang belajar untuk mengadakan perubahan tingkah laku, pada umumnya dengan beberapa indikator atau unsur yang mendukung. Sedangkan menurut Koeswara dalam Dimyati dan Mudjiono (2006:80) mengartikan motivasi belajar sebagai: Kekuatan mental yang mendorong terjadinya belajar. Kekuatan mental tersebut berupa keinginan, perhatian, kemauan atau cita- cita. Adanya keinginan atau cita-cita, maka siswa akan bersungguh- sungguh dalam mengikuti pembelajaran. Siswa akan memperhatikan penjelasan dari guru dan ikut berpartisipasi aktif dalam proses pembelajaran. Berdasarkan beberapa pendapat di atas, peneliti menyimpulkan bahwa motivasi belajar adalah daya penggerak atau dorongan internal maupun eksternal pada seorang siswa untuk melakukan suatu perubahan dalam belajar baik kognitif, afektif, dan psikomotor guna mencapai prestasi belajar yang optimal.

Menurut Syaiful Bahri Djamarah (2002: 90) menyatakan bahwa menyebutkan ada 3 (tiga) fungsi motivasi adalah untuk: Pendorong, perbuatan, penggerak perbuatan dan pengarah perbuatan.

Motivasi inilah yang akanmendorong siswa untuk melakukan kegiatan belajar. Selanjutnya, peran yangkhas dari motivasi adalah menumbuhkan gairah, merasa senang, semangat, dan mempunyai banyak energi untuk belajar. Oleh karena itu, jika peserta didik memiliki motivasi untuk belajar, maka peserta didik akan dengan segenap hati melakukan kegiatan apapun demi mencapai tujuannya tersebut. Dilihat dari hasil belajar pesrta didik kelas X SMA Muhammaduyah 1 Palangka Raya, diduga motivasi belajar yang dimiliki peserta didik masih rendah, karena jika motivasi belajar peserta didik tinggi, peserta didik tersebut akan melakukan kegiatan apapun demi mewujudkan hasil belajar yang tinggi. Begitu pula sebaliknya jika motivasi belajar peserta didik rendah, siswa akan enggan melakukan berbagai usaha untuk mencapai hasil belajar yang lebih tinggi, maka dari itu, perlu diketahui seberapa besarkah motivasi belajar yang dimiliki peserta didik kelas X SMA Muhammaduyah 1 Palangka Raya dan seberapa besarkah hubungannya terhadap hasil belajar di sekolah 
khususnya untuk mata pelajaran ekonomi.

Hasil belajar ekonomi peserta didik kelas X di SMA Muhammadiyah 1 Palangka Raya, pada saat peneliti melakukan observasi dilihat dari hasil Kriteria Ketuntasan Minimum (KKM), masih ada peserta didik yang belum tuntas. Berdasarkan data hasil belajar peserta didik dari nilai ulangan harian peserta didik, kelas $\mathrm{X}$ SMA Muhammadiyah Palangka Raya, khususnya pada mata pelajaran Ekonomi pada semester ganjil terdapat 47\% tidak tuntas dan 53\% tuntas. Nilai klasikal peserta didik kelas X SMA Muhammadiyah 1 Palangka Raya adalah 53\% (sesuai dg persentase yg tuntas).

Penelitian ini penting karena permasalahan penggunaan fasilitas belajar dan motivasi belajar pada peserta didik SMA Muhammadiyah 1 Palangka Raya sangat menarik untuk dilakukan penelitian, kemudian hasil penelitian dapat memberikan manfaat kepada sekolah, guru, peserta didik dan lain-lain. Berdasarkan kondisi di atas penulis tertarik untuk melakukan penelitian tentang Hubungan Penggunaan Fasilitas Belajar di Sekolah dan Motivasi Belajar Peserta didik dengan Hasil Belajar Ekonomi Kelas X di SMA Muhammadiyah 1 Palangka Raya Tahun Ajaran 2016/2017.

\section{METODE PENELITIAN}

Jenis penelitian ini menggunakan pendekatan data kuantitatif. Pendekatan data kuantitatif adalah semua informasi atau data yang diperoleh diwujudkan dengan angka.
Metode adalah hal yang sangat penting dalam penelitian sebab tanpa adanya metode, penelitian tidak dapat dipertanggungjawabkan secara ilmiah. Metode yang akan digunakan dalam penelitian ini menggunakan motode korelasional. Karena penelitian ini berusaha menelaah hubungan antara satu variabel dengan variabel yang lainnya dan menemukan ada tidaknya hubungan di antara variabel tersebut.

\section{HASIL DAN PEMBAHASAN}

Setelah melakukan analisis data untuk pengujian hipotesis, maka langkah selanjutnya adalah melakukan pembahasan terhadap hasil analisis data. Pembahasan analisis data adalah sebagai berikut:

1. Adanya hubungan penggunaan fasilitas belajar dengan hasil belajar ekonomi pada kelas X di SMA Muhammadiyah 1 Palangka Raya, dinyatakan diterima. Hal ini disebabkan karena $r_{\text {hitung }}>r_{\text {tabel }}$ yaitu 0, $206>0$, 195. Hal tersebut menunjukkan adanya hubungan yang positif antara penggunaan fasilitas belajar dengan hasil belajar ekonomi pada peserta didik kelas X SMA Muhammadiyah 1 Palangka Raya tahun pelajaran 2017/2018. Hal tersebut didasarkan kepada hasil dari penyebaran angket tersebut menunjukkan bahwa ada keterkaitan antara penggunaan fasilitas belajar dengan hasil belajar ekonomi. Keterkaitan tersebut ditunjukkan dengan adanya hubungan yang positif dan signifikan antara variabel penggunaan fasilitas belajar $\left(\mathrm{X}_{1}\right)$ dengan hasil belajar ekonomi (Y) 
pada pengolahan data. Berdasarkan perhitungan koefisien determinasi hubungan antara variabel $\mathrm{X}_{1}$ dengan variabel Y ditemukan sebesar 4, 24\% termasuk pada kategori rendah. Jadi terdapat hubungan yang masih rendah antara penggunaan fasilitas belajar dengan hasil belajar ekonomi.

2. Hubungan antara variabel motivasi belajar $\left(X_{2}\right)$ dengan hasil belajar ekonomi (Y) Hipotesis yang berbunyi Adanya hubungan motivasi belajar dengan hasil belajar ekonomi pada kelas $X$ di SMA Muhammadiyah 1 Palangka Raya, dinyatakan diterima. Hal ini disebabkan karena $\mathrm{r}_{\text {hitung }}>\mathrm{r}_{\text {tabel }}$ yaitu 0 , $225>0,195$. Hal tersebut menunjukkan bahwa terdapat hubungan yang signifikan antara variabel motivasi belajar $\left(\mathrm{X}_{2}\right)$ dengan variabel hasil belajar ekonomi pada peserta didik kelas X SMA Muhammadiyah 1 Palangka Raya tahun pelajaran 2017/2018. Hasil dari penyebaran angket tersebut menunjukkan bahwa ada keterkaitan antara motivasi belajar dengan hasil belajar ekonomi. Keterkaitan tersebut ditunjukkan dengan adanya hubungan yang positif dan signifikan antara variabel motivasi belajar $\left(\mathrm{X}_{1}\right)$ dengan hasil belajar ekonomi (Y) pada pengolahan data. Berdasarkan perhitungan koefisien determinasi hubungan antara variabel $\mathrm{X}_{2}$ dengan variabel Y ditemukan sebesar 5, 06\% termasuk pada kategori rendah. Jadi terdapat hubungan yang masih rendah antara motivasi belajar dengan hasil belajar ekonomi. Hubungan antara variabel fasilitas belajar dan motivasi belajar $\left(\mathrm{X}_{1}, \mathrm{X}_{2}\right)$ dengan prestasi belajar $(\mathrm{Y})$ Hipotesis yang berbunyi Adanya hubungan penggunaan fasilitas belajar dan motivasi dengan hasil belajar ekonomi pada kelas $\mathrm{X}$ di SMA Muhammadiyah 1 Palangka Raya, dinyatakan diterima karena disebabkan $r_{\text {hitung }}>r_{\text {tabel }}$ yaitu 0,298 $>$ 0, 195 Hal tersebut menunjukkan bahwa terdapat hubungan yang signifikan antara variabel penggunaan fasilitas belajar $\left(\mathrm{X}_{1}\right)$ dan motivasi belajar $\left(\mathrm{X}_{2}\right)$ dengan variabel hasil belajar siswa ekonomi (Y). Berdasarkan hasil penelitian dapat dibuat suatu kesimpulan bahwa hasil belajar dapat dipengaruhi oleh faktor penggunaan fasilitas belajar dan motivasi belajar. Hasil belajar peserta didik akan menjadi lebih baik apabila penggunaan fasilitas belajar yang baik dan mendukung peserta didik untuk mendapatkan hasil belajar yang lebih baik lagi. Berdasarkan perhitungan koefisien determinasi hubungan antara variabel $\mathrm{X}_{1}$ dan $\mathrm{X}_{2}$ dengan variabel $\mathrm{Y}$ ditemukan sebesar $8,88 \%$ termasuk pada kategori rendah. Jadi terdapat hubungan yang masih rendah antara penggunaan fasilitas belajar dan motivasi belajar dengan hasil belajar ekonomi.

\section{KESIMPULAN}

Ada hubungan yang positif antara penggunaan fasilitas belajar dengan hasil belajar ekonomi pada peserta didik kelas X SMA Muhammadiyah 1 Palangka Raya tahun pelajaran 2017/2018. Dengan koefisien 
korelasinya sebesar 0,206 dan $\mathrm{r}_{\text {tabel }}$, dengan nilai $\mathrm{df}=104-2=102, \mathrm{~N}=$ 102 dan $\mathrm{a}=0,05$ didapat $\left(\mathrm{r}_{\text {tabel }}\right)=0$, 195 jadi $\mathrm{r}$ hitung $>\mathrm{r}$ tabel. Hubungan tersebut termasuk dalam kategori rendah karena berdasarkan perhitungan koefisien determinasi hubungan antara penggunaan fasilitas belajar dengan hasil belajar ekonomi ditemukan sebesar 4, 24\% sedangkan sisanya sebesar 95, 76\% dipengaruhi oleh faktor lain yang tidak dibahas dalam penelitian ini.

Ada hubungan yang positif antara motivasi belajar dengan hasil belajar ekonomi pada peserta didik kelas X SMA Muhammadiyah 1 Palangka Raya tahun pelajaran 2017/2018. Dengan koefisien korelasinya sebesar 0,225 dan $\mathrm{r}_{\text {tabel}}$, demgan nilai $\mathrm{df}=104-2=102$, $\mathrm{N}=102$ dan $\mathrm{a}=0,05$ didapat $(\mathrm{r}$ tabel $)=$ 0,195 jadi $\mathrm{r}$ hitung $>\mathrm{r}_{\text {tabel. Hubungan }}$ tersebut termasuk dalam kategori rendah karena berdasarkan perhitungan koefisien determinasi hubungan antara motivasi belajar dengan hasil belajar ekonomi ditemukan sebesar 5, 06\% sedangkan sisanya sebesar 94, 94\% dipengaruhi oleh faktor lain yang tidak dibahas dalam penelitian ini.

Ada hubungan bersama yang positif antara penggunaan fasilitas belajar dan motivasi belajar dengan hasil belajar ekonomi pada peserta didik kelas X SMA Muhammadiyah 1 Palangka Raya tahun pelajaran 2017/2018. Dengan koefisien korelasinya sebesar 0, 298 dan rtabel, dengan nilai $\mathrm{df}=104-3=101, \mathrm{~N}=$ 101 dan $\mathrm{a}=0,05$ didapat $\left(\mathrm{r}_{\text {tabel }}\right)=0$, 195 jadi $\mathrm{r}$ hitung $>\mathrm{r}$ tabel. Hubungan tersebut termasuk dalam kategori rendah karena berdasarkan perhitungan koefisien determinasi hubungan antara penggunaan fasilitas belajar dan motivasi belajar dengan hasil belajar ekonomi ditemukan sebesar 8, 88\% sedangkan sisanya sebesar 91, $12 \%$ dipengaruhi oleh faktor lain yang tidak dibahas dalam penelitian ini.

\section{DAFTAR PUSTAKA}

Dalyono. (2012). Psikologi Pendidikan. Jakarta: Rineka Cipta.

Dimyati dan Mudjiono. (2006). Belajar dan Pembelajaran. Jakarta: Rineka Cipta.

Sardiman. (2012). Interaksi dan Motivasi Belajar Mengajar. Bandung: PT Raja Grafindo.

Slameto. (2010). Belajar dan Faktorfaktor yang Mempengaruhinya. Rev. Jakarta: PT Rineka Cipta.

Undang-Undang Pendidikan No 20 Tahun 2003. Tentang Sistem Pendidikan Nasional. Jakarta: Sekretariat Negara

Uno, Hamzah B. (2012). Teori Motivasi \& Pengukurannya. Jakarta: Bumi Aksara. 